\title{
KONFORMITAS PETANI DALAM USAHATANI KEDELAI (Suatu Kasus di Kecamatan Jatiwaras Kabupaten Tasikmalaya, Provinsi Jawa Barat)
}

\author{
FARMERS 'CONFORMITY IN SOYBEANS CULTIVATION \\ (Case in Jatiwaras Subdistrict, Tasikmalaya District, West Java Province)
}

\author{
Ivan Sayid Nurahman ${ }^{1 *}$, Iwan Setiawan², Trisna Insan Noor ${ }^{2}$, Meddy Rachmadi \\ ${ }^{1}$ Fakultas Pertanian, Universitas Galuh \\ ${ }^{2}$ Fakultas Pertanian, Universitas Padjadjaran \\ *Email: v.sayid9@gmail.com
}

(Diterima 24-07-2019; Disetujui 30-07-2019)

\begin{abstract}
ABSTRAK
Konformitas adalah tekanan untuk memiliki sikap atau memiliki perilaku dalam suatu cara yang konsisten dengan aturan-aturan yang menunjukkan orang seharusnya berperilaku. Penelitian ini bertujuan untuk mengetahui penyebab petani melakukan konformitas pada kelompok tani, dan bagaimana sistem nilai dan norma yang berlangsung dalam kelompok tani sehingga dapat mengatur perilaku dan mengarahkan cara berpikir anggotanya. Hasil penelitian menunjukkan faktor yang paling dominan mempengaruhi perilaku petani kedelai di Kecamatan Jatiwaras untuk melakukan konformitas antara lain adalah kepercayaan dan kekompakan. Tingginya kepercayaan dan eratnya hubungan antara individu (kekompakan) terhadap kelompok menimbulkan konformitas yang semakin tinggi. Sebaliknya persamaan pendapat dan kesepakatan termasuk kategori rendah sehingga bila terdapat perbedaan pendapat terhadap kesepakatan kelompok akan tampak adanya penurunan tingkat konformitas. Cara berpikir dan perilaku petani kedelai cenderung berdasarkan rasionalitas, sehingga ketaatan terhadap anjuran dan aturan dalam kelompok seringkali diabaikan.
\end{abstract}

Kata kunci: konformitas petani, kelompok, usahatani kedelai

\section{ABSTRACT}

Conformity is the pressure to have an attitude or to have behavior in a way that is consistent with rules that show people should behave. This study aims to determine the causes of farmers to conform to farmer groups, and how do the system of values and norms take place within the farmer group so that they can regulate behavior and direct the way of thinking of its members. The results showed that the most dominant factors affecting the behavior of soybean farmers in Jatiwaras Subdistrict to conduct conformity included trust and cohesiveness. The high level of trust and the close relationship between individuals (cohesiveness) towards the group raises increasingly high conformity. On the contrary, equality of opinion and agreement are included in the low category so that if there is a difference of opinion on the group agreement there will be a decrease in the level of conformity. The way of thinking and behavior of soybean farmers tends to be based on rationality, so obedience to recommendations and rules in groups is often ignored.

Keywords: conformity of farmers, groups, soybean farming

\section{PENDAHULUAN}

Kedelai merupakan tanaman pangan utama strategis terpenting setelah padi dan jagung. Begitu besarnya kontribusi kedelai dalam hal penyediaan bahan pangan bergizi bagi manusia sehingga kedelai biasa dijuluki sebagai gold from the soil, atau sebagai world's 
miracle mengingat kualitas asam amino proteinnya yang tinggi, seimbang dan lengkap (Mursidah, 2005).

Produksi kedelai dalam negeri terus menurun seiring dengan merosotnya areal tanam. Hal tersebut menunjukkan kurangnya minat petani untuk menanam kedelai. Sehingga untuk mencukupi permintaan kedelai dalam negeri yang terus meningkat pemerintah dengan terpaksa melakukan impor. Diperlukan upaya untuk menjaga agar tidak terjadi ketergantungan terhadap impor kedelai dengan seperangkat kebijakan, baik kebijakan insentif maupun protektif dalam memacu peningkatan produksi kedelai dalam negeri.

Pelaksanaan program swasembada kedelai yang dirancang Departemen Pertanian sejak tahun 1996 dalam implementasinya sering tergeser oleh prioritas lain, khususnya beras. Oleh karena itu, menurut Rusastra et al (2002), bahwa secara umum fokus pembangunan nasional perlu berpihak pada kondisi riil struktur ekonomi yang berbasis sumberdaya dan keunggulan wilayah. Dalam hal ini, sudah saatnya posisi sektor pertanian dijadikan sebagai the leading sector karena peranannya sangat penting dalam perekonomian Indonesia.
Kurangnya partisipasi dan minat petani untuk menanam kedelai karena nilai ekonomisnya kurang menguntungkan dibandingkan dengan komoditas lain (Zakaria, 2010). Hal tersebut apabila dipandang dari aspek ketercapaian program pemerintah yang berorientasi pada produksi. Namun jika dilihat lebih lanjut masih adanya petani yang bertahan dan mau menanam kedelai mereka cenderung berorientasi pada pendapatan, dimana mereka melakukan beberapa tindakan yang mereka anggap sebagai suatu tindakan yang rasional. Diantaranya dengan melakukan panen hijau dan pola tanam tumpangsari. Hal tersebut yang disebut oleh Robert Merton (1968) sebagai Conformity (konformitas) dimana itu bukan merupakan suatu tindakan memberontak atau menentang tujuan pemerintah melainkan adaptasi menciptakan kondisi sesuai dengan yang dibutuhkan sebagian besar petani atau kelompok tani. Penelitian ini bertujuan untuk mengetahui penyebab petani melakukan konformitas pada kelompok tani. Kemudian bagaimana sistem nilai dan norma yang berlangsung dalam kelompok tani sehingga dapat mengatur perilaku dan mengarahkan cara berpikir anggotanya. 


\section{METODE PENELITIAN}

Penelitian ini menggunakan metode survey deskriptif pada petani kedelai di Kecamatan Jatiwaras, yang merupakan salah satu sentra produksi kedelai di Kabupaten Tasikmalaya, Provinsi Jawa Barat. Teknik pengambilan sampel dilakukan dengan simple random sampling dari 185 populasi petani di Kecamatan Jatiwaras, kemudian untuk penentuan ukuran sampel dihitung dengan menggunakan Rumus Slovin maka diperoleh ukuran sampel sebanyak 127 petani. Data dikumpulkan menggunakan kuesioner dengan skala Likert. Kemudian data ditabulasikan berdasarkan persentase jawaban responden dan dianalisis secara deskriptif kualitatif sehingga dapat ditarik suatu kesimpulan.

\section{HASIL DAN PEMBAHASAN}

Konformitas adalah tekanan untuk memiliki sikap atau memiliki perilaku dalam suatu cara yang konsisten dengan aturan-aturan kelompok di mana individu seharusnya berperilaku. Aturan-aturan tersebut sering disebut dengan istilah norma sosial yang memberi pengaruh yang kuat terhadap perilaku seseorang sebagai bagian dari suatu kelompok (Spradley dan David, 2012). Konformitas dapat dilihat sebagai salah satu bentuk pengaruh sosial (social influence) yang mempengaruhi terjadinya perilaku individu. Sears, dkk (1994) mengemukakan bahwa konformitas seseorang ditandai dengan adanya tiga hal, yakni kekompakan, kesepakatan, dan ketaatan.

Adanya hubungan yang erat antar petani serta harapan memperoleh manfaat dari keanggotaannya dalam kelompok, maka akan semakin kompak kelompok tersebut. Kekompakan yang tinggi akan menimbulkan tingkat konformitas yang semakin tinggi. Peningkatan konformitas juga terjadi karena anggotanya enggan disebut sebagai orang yang menyimpang. Orang yang terlalu sering menyimpang pada saat-saat yang penting diperlukan, tidak menyenangkan dan bahkan bisa dikeluarkan dari kelompoknya. Kesepakatan dalam sebuah kelompok dibuat untuk memiliki tekanan sehingga petani harus bisa menyesuaikan pendapatnya dengan kesepakatan yang sudah dibuat dalam kelompok. Hancurnya kesepakatan dalam kelompok yang disebabkan oleh faktor kepercayaan akan menyebabkan penurunan konformitas. Rendahnya tingkat kepercayaan individu petani terhadap mayoritas petani dalam kelompok akan menurun apabila terjadi perbedaan 
pendapat di dalamnya, meskipun orang yang berbeda pendapat sebenarnya kurang ahli bila dibandingkan dengan anggota yang membentuk mayoritas. Adanya seseorang yang tidak sependapat menunjukkan terjadinya perbedaan yang dapat berakibat pada berkurangnya kesepakatan kelompok. Ketika tekanan dan tuntutan dalam sebuah kelompok akan membuat petani rela melakukan tindakan apapun meskipun petani itu sendiri tidak menginginkannya. Bila ketaatan itu tinggi maka konformitasnya akan tinggi pula. Salah satu untuk menimbulkan ketaatan adalah dengan meningkatkan tekanan terhadap individu untuk menampilkan perilaku yang diinginkan melalui ganjaran, hukuman atau sanksi baik itu sanksi administrasi ataupun sanksi sosial.

Maka yang dimaksud dengan konformitas dalam penelitian ini adalah bentuk interaksi yang dapat membuat seorang petani dapat berperilaku sesuai dengan harapan kelompoknya. Terdiri atas beberapa indikator konformitas yang dikembangkan, yaitu: kekompakan dalam kegiatan gotong royong membangun sarana dan prasarana untuk mendukung kegiatan usahatani merupakan suatu kekuatan kelompok yang memberikan manfaat pada anggotanya, kesepakatan dalam penentuan pola tanam yang harus diterapkan oleh petani, kepercayaan terhadap cara budidaya atau penerapan teknologi yang diterapkan oleh mayoritas petani, persamaan pendapat dalam penentuan waktu tanam dan waktu panen kedelai, dan ketaatan terhadap aturan dan anjuran kelompok tani yang sudah dibuat. Hasil penelitian (Gambar 1) menunjukkan bahwa kekompakan petani kedelai dalam kelompok tani di Kecamatan Jatiwaras dalam kondisi baik atau kategori tinggi, sementara itu kesepakatan petani dalam penentuan pola tanam tergolong rendah. Dapat dipahami bahwa kekompakan yang terbangun dalam kelompok merupakan sumber dari konformitas petani, dengan tergabungnya petani dalam kelompok dan partisipasi aktifnya dalam setiap kegiatan membuat mereka merasakan manfaat yang begitu besar dari keikutsertaannya dalam kelompok. Rendahnya kesepakatan petani dalam kelompok berkaitan juga dengan masih banyaknya petani yang berbeda pendapat mengenai pola tanam, penerapan teknologi dan penentuan waktu tanam-panen yang harus diterapkan oleh petani. 


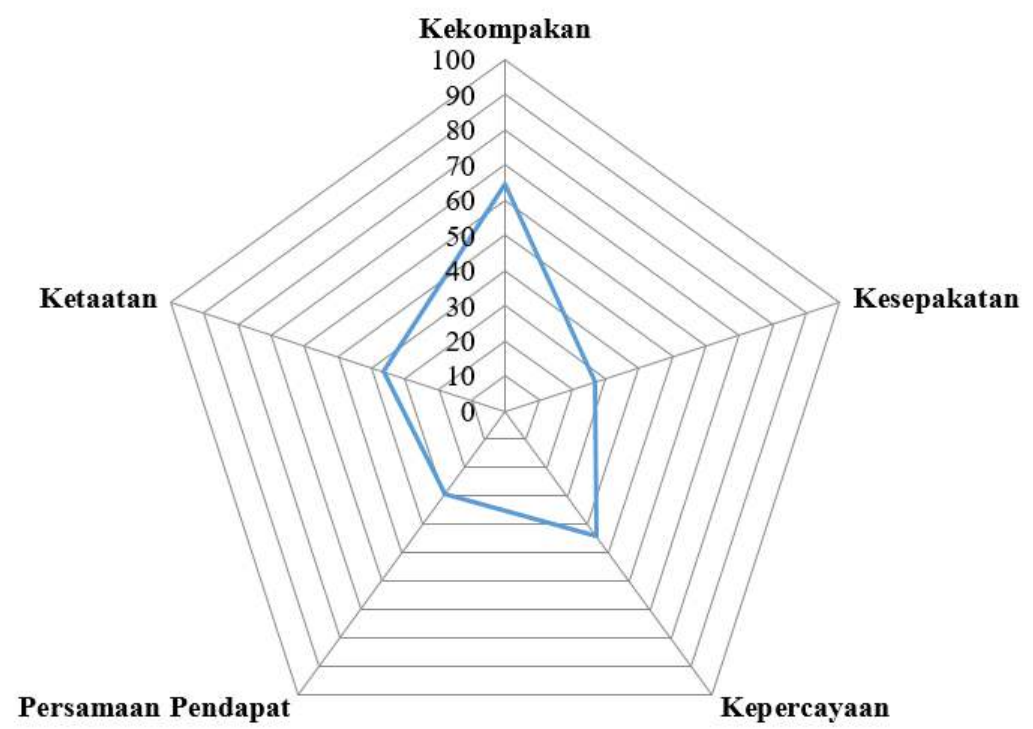

Gambar 1. Persentase Hasil Analisis Konformitas Petani dalam Usahatani Kedelai

\section{Kekompakan}

Kekompakan di dalam kelompok diukur dari partisipasi dalam kegiatan gotong royong membangun sarana dan prasarana untuk mendukung kegiatan usahatani, peran anggota pada kegiatan kelompok dan kerjasama antar anggota dalam kegiatan tersebut mencerminkan kekompakan dalam kelompok. Kekompakan petani dalam kelompok tani di Kecamatan Jatiwaras termasuk dalam ketegori tinggi dengan jumlah 82 orang atau 64,57 persen. Hal tersebut karena dalam kelompok tani terjalin hubungan yang baik antar anggota, baik di dalam kelompok maupun di luar kelompok. Di samping itu, anggota selalu berperan dalam setiap kegiatan kelompok, dengan terjalinnya hubungan yang baik antar anggota dan peran anggota dalam setiap kegiatan maka tercipta kerjasama yang baik antar anggota berdasarkan tujuan kelompok. Hal ini sejalan dengan hasil penelitian Astuti (2010) yang menunjukkan bahwa kekompakan kelompok dapat dilihat melalui kerjasama anggota dalam melaksanakan setiap kegiatan, solidaritas anggota serta adanya kerjasama yang baik dalam kelompok akan berpengaruh terhadap setiap kegiatan-kegiatan yang dilakukan dalam kelompok, sehingga kepuasan anggota akan semakin mudah tercapai.

\section{Kesepakatan}

Petani yang menyatakan bahwa sepakat terhadap penentuan pola tanam yang harus diterapkan oleh petani dalam kelompok sebanyak 34 orang atau 26,77 persen. Hal tersebut karena pola tanam 
yang diterapkan petani di Kecamatan Jatiwaras begitu variatif. Sangat bisa dipahami bahwa tindakan tersebut merupakan bentuk rasionalitas petani untuk meminimalisir risiko kegagalan dan bukan merupakan bentuk pembangkangan terhadap kelompok. Hal tersebut sejalan dengan pendapat Polakitan (2013) yang menyatakan bahwa pola tanam campuran atau tumpangsari dalam sehamparan lahan, pemilihan komoditas merupakan faktor yang menentukan tingkat keberhasilan usahatani. Jenis tanaman yang ditanam sehamparan lahan harus saling mendukung (komplementer).

\section{Kepercayaan}

Kepercayaan petani terhadap kelompok mengenai cara budidaya atau penerapan teknologi yang harus diterapkan oleh mayoritas petani kedelai di Kecamatan Jatiwaras termasuk kategori tinggi. 56 orang atau 44,09 persen petani menyatakan bahwa mereka percaya dengan cara budidaya atau penerapan teknologi yang diterapkan oleh sebagian besar petani dalam kelompok yang menerapkan teknologi sederhana dan input minimal akan memberikan manfaat dan keuntungan bagi mereka. Sejalan dengan teori produksi Soekartawi
(1990) yang menyatakan bahwa dalam penerapan teknologi seorang petani akan berorientasi pada efisiensi ekonomis yakni fokus pada produksi output dengan jumlah tertentu dengan menggunakan input yang minimal.

\section{Persamaan Pendapat}

Kondisi sebagian besar lahan di Kecamatan Jatiwaras yang merupakan lahan tadah hujan sehingga hanya mengandalkan hujan untuk pemenuhan kebutuhan air. Dwiratna et al (2016) menyatakan bahwa penentuan jadwal tanam sangat diperlukan agar kegagalan panen dapat dihindari sehingga keuntungan maksimum dapat diperoleh. Sebanyak 37 orang atau 29,14 persen petani memiliki pendapat yang berbeda mengenai penentuan waktu tanam dan waktu panen kedelai petani di Kecamatan Jatiwaras. Hal tersebut disebabkan setiap individu petani memiliki pengetahuan dan pengalaman yang berbeda dalam membaca kondisi cuaca dan iklim untuk menentukan waktu tanam. Serta dalam penentuan waktu panen pula masih banyak petani yang lebih memilih panen hijau yang disebabkan oleh terdesaknya kebutuhan. 


\section{Ketaatan}

Ketaatan petani dalam menaati aturan dan anjuran kelompok tani hanya mencapai 36,22 persen (46 orang). Masih adanya sebagian petani yang belum taat akan aturan dan anjuran kelompok merupakan suatu hal yang biasa terjadi dalam sebuah kelompok dimana setiap individu memiliki pandangan dan idealisme yang berbeda terhadap suatu aturan dan anjuran. Sebagaimana dinyatakan oleh Pewista dan Harini (2013) bahwa persepsi masyarakat sangat dipengaruhi oleh adat dan budaya setempat. Petani yang budaya bertaninya tinggi mempunyai ketaatan aturan, ketaatan cara dalam usahatani, mempunyai kebiasaan yang teratur sehingga dimungkinkan menilai suatu yang baru secara biasa saja (menganggap tidak rumit, mudah dicoba dan mudah diamati).

\section{KESIMPULAN DAN SARAN}

Dapat disimpulkan bahwa faktor yang paling dominan mempengaruhi perilaku petani kedelai di Kecamatan Jatiwaras untuk melakukan konformitas antara lain adalah kepercayaan dan kekompakan. Tingginya kepercayaan dan eratnya hubungan antara individu (kekompakan) terhadap kelompok menimbulkan konformitas yang semakin tinggi. Sebaliknya persamaan pendapat dan kesepakatan termasuk kategori rendah sehingga bila terdapat perbedaan pendapat terhadap kesepakatan kelompok akan tampak adanya penurunan tingkat konformitas. Cara berpikir dan perilaku petani kedelai cenderung berdasarkan rasionalitas, sehingga ketaatan terhadap anjuran dan aturan dalam kelompok seringkali diabaikan. Hal-hal tersebut pada akhirnya diharapkan dengan konformitas petani kedelai akan berimplikasi positif terhadap keselarasan orientasi pengembangan kedelai antara pemerintah, kelompok dan individu petani sendiri demi tercapainya peningkatan kesejahteraan petani dan keberlanjutan usahatani kedelai di Kecamatan Jatiwaras.

\section{DAFTAR PUSTAKA}

Astuti, Aini Nur. 2010. Analisis Efektivitas Kelompok Tani di Kecamatan Gatak Kabupaten Sukoharjo. Program Studi Penyuluhan dan Komunikasi Pertanian. Universitas Sebelas Maret. Surakarta.

Perwitasari, S.D.N, Suryadi, S. dan Kamaratih, K.D. 2016. Optimasi Pola Tanam Pada Lahan Sawah Tadah Hujan Di Kecamatan Cimanggung Kabupaten Sumedang. Jurnal Teknotan 10(1): $37-45$. 
Mursidah. 2005. Perkembangan Produksi Kedelai Nasional dan Upaya Pengembangannya di Provinsi Kalimantan Timur. Kalimantan: LIPI.

Pewista, I dan R Harini. 2013. Faktor dan pengaruh alih fungsi lahan pertanian terhadap kondisi sosia ekonomi penduduk di Kabupaten bantul. Kasusu daerah perkotaan, pinggiran dan pedesaan Tahun 2001-2010. Jurnal Bumi Indonesia, 2(2): 96-103.

Polakitan, A. 2013. Optimalisasi Pemanfaatan Lahan dengan Tumpangsari Kedelai dan Ubi Jalar. Prosiding Seminar Hasil Penelitian Tanaman Aneka Kacang dan Umbi.

Merton, Robert K. 1968. Social Theory and Social Structure. New York: The Free Press.

Rusastra, I W., P. Simatupang, dan B. Rachman. 2002. Pembangunan ekonomi perdesaan berlandaskan agribisnis. dalam T. Sudaryanto dan E. Pasandaran (Ed.). Analisis
Kebijakan: Pembangunan pertanian andalan berwawasan agribisnis. Monograph Series No. 23. Pusat Penelitian dan Pengembangan Sosial Ekonomi Pertanian, Bogor.

Sears, David O., Freedman, Jonathan L., \& Peplau, L. A. 1994. Psikologi Sosial jilid 2. Alih Bahasa: Michael Adryanto. Erlangga. Jakarta.

Soekartawi. 1990. Teori Ekonomi Produksi: Dengan Pokok Bahasan Analisis Cobb Douglas. Rajawali Pers: Jakarta.

Spradley, J.P. dan David W. McCurdy. 2012. Conformity and Conflict. Readings in Cultural Anthropology. Fourteenth Edition. Boston: Little, Brown and Company Inc.

Zakaria, Amar K. 2010. Dampak Penerapan Teknologi Usahatani Kedelai di Agrosistem Lahan Kering Terhadap Pendapatan Petani. Agrika 4(2): 67-78. 